
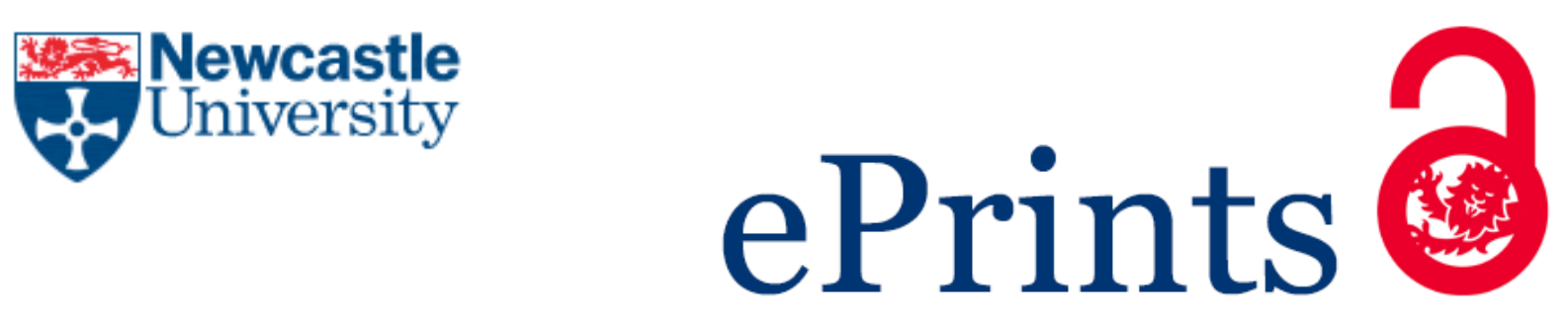

Agha R, Kamara JM.

Adaptations in Traditional Courtyard Houses in Baghdad, Iraq. International Journal of Building Pathology and Adaptation 2017, 35(4), 348363.

\title{
Copyright:
}

This is the authors' accepted manuscript of an article that was published in its final definitive form by Emerald, 2017.

DOI link to article:

https://doi.org/10.1108/IJBPA-03-2017-0013

Date deposited:

$12 / 07 / 2017$

Embargo release date:

14 August 2018 


\section{Adaptations in Traditional Courtyard Houses in Baghdad, Iraq}

ABSTRACT

Purpose

This paper investigates the adaptations that have been made to traditional courtyard houses (TCH) in Bagdad, Iraq. The aim is to develop an understanding of various factors in the adaptation of these buildings to suit contemporary lifestyles, which will contribute to the wider field of building adaptability.

\section{Design/methodology}

Empirical evidence was collected through case studies of $12 \mathrm{TCHs}$ in the Al-Kadhimiya area of Baghdad, which involved a physical survey of buildings and semi-structured interviews with 24 occupants.

\section{Findings}

Case study analysis show that building adaptability involves both a change to physical spaces and also to lifestyles; with the latter being more likely when there are limitations in how much change can be made to the physical structure.

\section{Research limitations/implications}

The focus of this research is mainly on users' adaptation of spaces and therefore does not consider the full range of stakeholders involved in the adaptation process. The findings also only apply to the cases considered and may not be applicable to other house types or locations.

\section{Originality/value}

Studies on building adaptability mostly focus on the ease of change to the building fabric, although the role of users is acknowledged. This study provides insights into the complexity and variety of changes that users can make, which are influenced by lifestyles and driven by the need for comfort. These insights are represented in an adaptation model, which can serve as a basis for further research.

KEYWORDS: Bagdad, building adaptability, Iraq, lifestyle, traditional courtyard house, user adaptations

Article Classification: Research Paper

\section{INTRODUCTION}

Buildings are an important component of any society. Apart from their primary function of providing shelter and space for various activities, they also contribute to the culture, heritage, and wealth of a society, as well as impact the natural environment.

As fixed assets with a relatively long lifespan, they are subject to changes to ensure that they remain fit for purpose at any given time. Many factors can drive such changes, e.g. the need to accommodate different uses and functions, to comply with new legislation, to respond to changes in the external environment, or to preserve and extend their useful life because of their cultural importance (Bullen, 2007; Kelly et al. 2011; Thompson et al. 2014). And the scale of changes can range from day-to-day adjustments of furniture in a space, to major refurbishments that sometimes result in a change of use of the building.

This paper explores the adaptations that have been made to Traditional Courtyard Houses (TCH) in Bagdad, Iraq. The aim is to develop an understanding of how these changes compare with current understanding and practice of building adaptability. The next two sections present an overview of 
building adaptability and Traditional Courtyard Houses (TCHs) respectively. This is followed by a description of the research methodology and thereafter a presentation and discussion of the findings of the research, and the conclusions drawn from it.

\section{BUILDING ADAPTABILITY}

Changes to buildings over time are made possible by how easy it is to make those changes. That is, with respect to its adaptability, defined as: "the capacity of a building to accommodate effectively the evolving demands of its context, thus maximizing value through life" (Schmidt III et al, 2010). This 'capacity to be changed' can be pre-configured during the conception and design of the building, or it can be re-configured in use (Beadle et al. 2008). Strategies to build in adaptability include the use of modular grids, raised floors (Arge, 2005); simple, regular layouts, common, standard shapes and connections, fewer large members rather than many small members, and over-designing to allow for future adaptation (Webster, 2007).

Another key consideration for adaptability is to conceive a building as having layers, with each layer having different rates of change. Brand (1994) identifies six such layers: site, structure, skin, services, space, and stuff (e.g. furniture), and Table 1 summarises the types of change, decision level, scale, and rate of change (timescale) for each of these layers. Given the different timescales for changes to each layer, avoiding the intermingling of layers (e.g. embedding services in the structure of a building) can lead to more adaptability (Webster, 2007).

Table 1. Summary of adaptability strategies in relationship to other dimensions (slightly modified from Schmidt III et al. 2010)

\begin{tabular}{|c|c|c|c|c|c|c|c|c|c|}
\hline \multirow[b]{2}{*}{$\begin{array}{l}\text { Category (Type of } \\
\text { change) }\end{array}$} & \multirow[b]{2}{*}{$\begin{array}{l}\text { Decision- } \\
\text { level }\end{array}$} & \multirow[b]{2}{*}{ B-E scale } & \multirow[b]{2}{*}{$\begin{array}{l}\text { Time (cycle } \\
\text { speed) }\end{array}$} & \multicolumn{6}{|c|}{ Brand's layers } \\
\hline & & & & 疍 & $\begin{array}{l}\stackrel{\Xi}{\pi} \\
\text { ஸे }\end{array}$ & 岕 & $\frac{5}{\text { v }}$ & 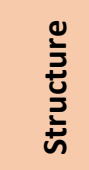 & $\stackrel{ \pm}{\frac{ \pm}{n}}$ \\
\hline $\begin{array}{l}\text { Adjustable (change } \\
\text { of task) }\end{array}$ & User & Components & $\begin{array}{l}\text { Daily/ } \\
\text { monthly }\end{array}$ & $x$ & & & & & \\
\hline $\begin{array}{l}\text { Versatile/ flexible } \\
\text { (change of space) }\end{array}$ & User & Components & $\begin{array}{l}\text { Daily/ } \\
\text { monthly }\end{array}$ & $x$ & $x$ & & & & \\
\hline $\begin{array}{l}\text { Refitable (change of } \\
\text { performance) }\end{array}$ & $\begin{array}{l}\text { User/ } \\
\text { owner }\end{array}$ & Components & 7 years & & $x$ & $\mathbf{x}$ & $x$ & & \\
\hline $\begin{array}{l}\text { Convertible (change } \\
\text { of function) }\end{array}$ & $\begin{array}{l}\text { User/ } \\
\text { owner }\end{array}$ & Building & 15 years & & $x$ & $x$ & $x$ & & \\
\hline $\begin{array}{l}\text { Scalable (change of } \\
\text { size) }\end{array}$ & Owner & Building & 15 years & & $x$ & $x$ & $x$ & $\mathbf{x}$ & \\
\hline $\begin{array}{l}\text { Movable (change of } \\
\text { location) }\end{array}$ & owner & building & 30 years & & & & & $x$ & $x$ \\
\hline
\end{tabular}

It should be noted that although the type of changes to buildings that are considered as 'adaptations' should be 'major works' that result in improvements and conversion of a building (Bullen, 2007, Gosling et al. 2013), the ability of users to make changes at the 'stuff' and 'space' layers (Table 1) can still be part of a wider framework of building adaptability. This then suggests that building adaptability should not only relate to the technical or physical aspects of buildings, as there are human and social dimension to it as well. Indeed, Brand (1994) observes that buildings do change people as much as 
people want to change buildings to suit their needs. While "the dynamics of the system [of change to buildings] will be dominated by the slow components [i.e. those with a longer cycle of change, e.g. the structure - Table 1] with the rapid components simply following along," frequent changes to 'stuff' can also lead to changes in spaces and services (Brand, 1994: 20).

\section{TRADITIONAL COURTYARD HOUSES}

Traditional Courtyard Houses (TCH) are an indigenous urban house form that has evolved over the last 6000 years in various regions of the work with different climates, cultures and building materials (Goh and Sibley, 2009). A TCH typically has an inner open space, the courtyard, which serves as the focal point for all other habitable spaces (Al-Zubaidi, 2007). It provides not only an appropriate microclimate to obtain light and natural ventilation, it also delivers the privacy, seclusion, security and social oneness required in such traditionalist societies (Shokouhian et al, 2007, p 971; Leylian et al. 2010).

TCHs do not have a precise shape and are linked from three sides, since other courtyard houses are built contiguously along these sides (Figure 1). In plan, they essentially consist of an interior courtyard with all family rooms grouped around three or all of its sides. In section, they can have one or two floors, a roof and some also have a basement (Warren and Worskett, 1983). TCHs can also vary in their size and number of courtyards, and can be categorised using these parameters. For example, larger, medium, or small (Agha, 2015), or one-courtyard, two, three and four-courtyards. The spaces in TCHs can also be categorised into usable spaces, transitional spaces and architectural physical elements (Muhaisen, 2006, El-Shorbagy, 2010)

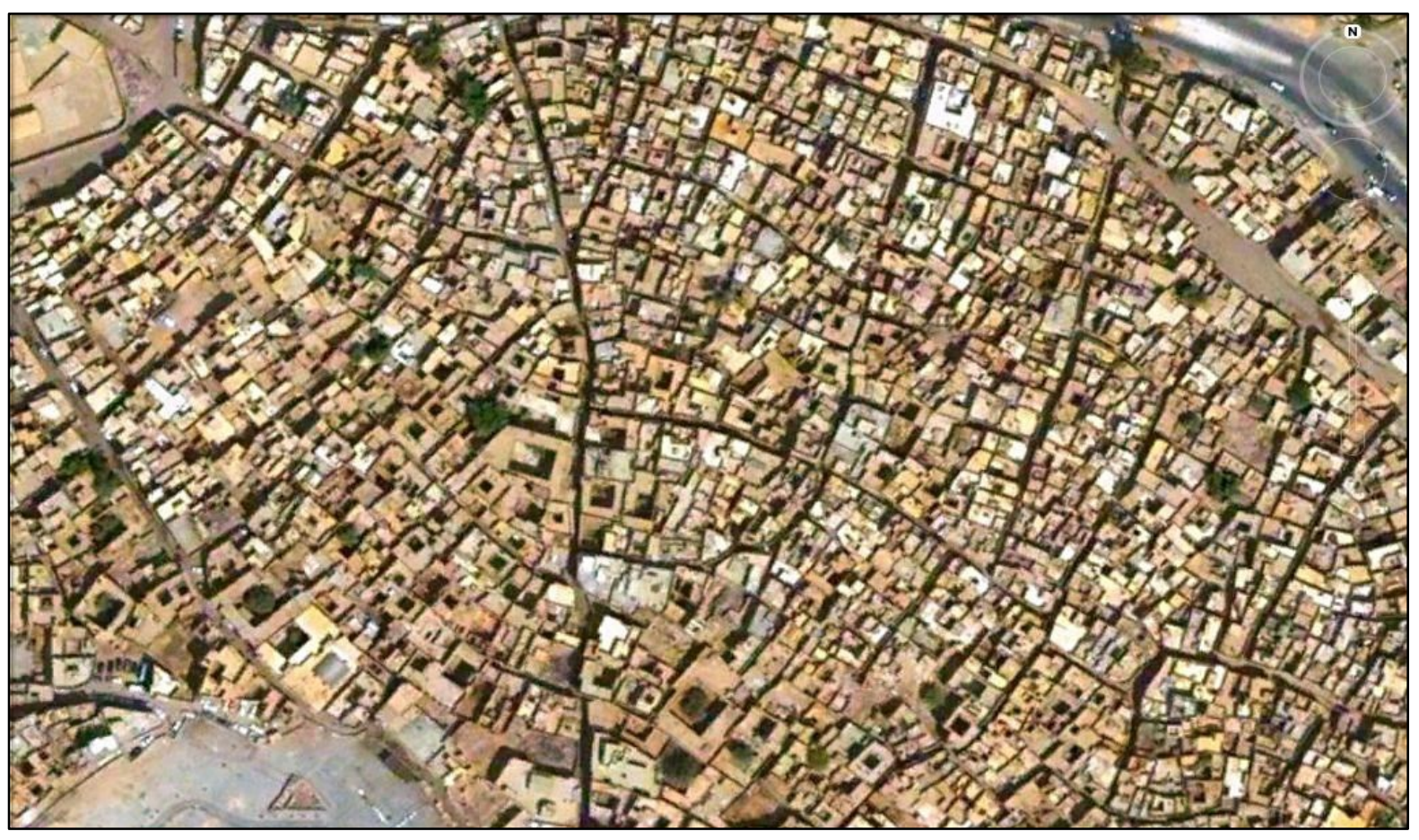

Figure 1. The compactness of TCH in Al-Kadhimiya as a contiguous and amorphous mass of buildings separated at random by winding shapes and narrow gaps viewed from the air. Google Earth (2011).

The use of spaces within TCHs varies according to the seasons and in response to external environmental conditions. During the cold season, the internal areas of the first floor are mostly used, with intermittent use of the ground floor spaces, and very little use of outdoor spaces. In the hotter periods, more use is made of the ground floor, basement and roof, and outdoor spaces (Al-Assawi, 1996B). In addition to seasonal movements, there are also vertical and horizontal movement across 
spaces, on a daily basis. During the hot season, occupants sleep on the roof, and descend to the ground floor in the morning. They often eat breakfast and lunch in the courtyard, and spend most of their time in the habitable rooms in the basement. At tea-time, they move up to the ground floor, have their mean in the courtyard and then proceed to the roof to sleep. Horizontal movements occur either within the courtyard or between spaces on the same level. At mid- or late morning, residents go from one side of the courtyard to the other to escape the direct sunlight. Around midday, as the sun spreads across most of the floor area of the courtyard, occupants leave the courtyard and go into the spaces on the ground floor. In late afternoon or early evening, movement is back from the semi-open spaces to the courtyard (Al-Azzawi, 199A).

However, various studies (e.g. Warren and Fethi, 1982; Yang, 2007, Azadi, 2008, Goh, 2010, and AlAkkam, 2013) have identified several problems and limitations of TCHs. These include overcrowding by extended families, deteriorating structures and slum conditions around courtyard houses, lack of maintenance, infrastructure and services. Also, the inexact shapes of TCHs make it difficult to optimise their performance and has led to the rejection of this form of housing by some people. But on the other hand, although they are high density and low rise, they provide affordable housing, social interaction, energy and scope for conservation that appeals to many people. And these have supported calls for their refurbishment to address the changing needs of their users. This paper, though examines the adaptations that users are making to these houses.

\section{RESEARCH METHODOLOGY}

The research reported in this paper was part of a wider research into the role of intelligent systems in enhancing the performance of Traditional Courtyard Houses (TCHs) in Bagdad, which was motivated by Iraqi Government efforts to refurbish and upgrade TCHs in historic areas of the city (Agha, 2016). This paper draws from an aspect of the research that focused on the nature of TCHs and the lifestyles of its users, to explore the adaptations that have been with a view to developing an understanding of the issues, processes and strategies involved, against the context of research and practice in building adaptability. It is therefore exploratory in nature. A qualitative approach was therefore adopted as it is considered most appropriate to address exploratory research questions (Yin 2003, Flyvbjerg, 2006). Key research questions were: what is the nature of TCHs and how do they support the lifestyles of current users? What adaptations have been made and how have these ben achieved? How do these contribute to the wider theory and practice of building adaptability?

The Al-Kadhimiya area of Bagdad, which is one of the historical areas of the city was selected as the focus of the study. This was mainly because of an active government plan to refurbish TCHs in this area, with the likely availability of relevant information on buildings that will be useful for the study. It was also the area that had less safety risks compared to the other historic areas. The strategy was to select a representation of different TCH buildings on which there was adequate documentation (e.g. category of $\mathrm{TCH}$, owner, architectural drawings, location and address) that will assist in the survey of these buildings to determine their specific features and adaptations made, and with willing occupants to interview in order to build a picture their lifestyles. Following a search in the Municipality of Bagdad, a number of buildings with adequate documentation were selected. Combined with the need for occupants to willingly grant access for the survey and be interviewed, $12 \mathrm{TCH}$ s were selected for the study.

Data collection was conducted by the lead author (with the assistance of trained local assistants) between March and June 2012, and involved a physical survey of houses and semi-structured interviews with 24 occupants ( 2 from each house; and a total of 8 men and 16 women). The physical survey was used to determine the number of courtyards, levels in the house, and number and function of the rooms; the orientation of the house, courtyard and spaces, and the location of different activities. Furthermore, the type of services, including electricity, lighting fixtures, cooling and heating equipment, water supply, drainage and sewage systems and possible e-communication, were also 
ascertained. There was also visual observation to capture, through photographs, some domestic activities which take place inside the houses. Interviewees were a mixture of male and female, from different ages, education and different levels of education. Interviews were conducted in the morning, due to the security situation in Bagdad at the time, and included themes on ownership of the house, number and demographics of occupants, occupations, level of occupancy, types of activities performed and spaces used in the house, and their general experience of living in TCHs. Interviews, which were conducted in Arabic, were mostly recorded on tape, lasted from between 60 and 120 minutes and were sometimes held individually or in pairs. The interviews were conducted after the surveys and the whole process for each house (i.e. survey and interview) lasted for about 4 to 5 hrs. Table 2 provides an overview of the tenancy, occupancy, basic characteristics of houses surveyed, and the composition of interviewees.

Data analysis for the physical survey involved the use of CAD tools to recreate and update drawings and piecing together and analysing photographic and other information about buildings. For the interviews, this involved the transcription and translation into English of all interview recordings, and the use of thematic analysis to identify and classify themes arising from the interviews.

Ethical issues were addressed by making sure all participants were informed about the objectives of the research and given the opportunity to give their full consent for the survey and interviews.

Apart from the usual limitations of case study research (e.g. inability to make generalisations), there were also other challenges to data collection, mainly due to restrictions of movement due to the security situation at the time of the study. This, for example made it difficult to revisit interviewees to validate interview transcripts and seek further clarifications on information. These limitations notwithstanding, meaningful data was collected to provide insights into the research questions.

\section{FINDINGS}

\section{Changes to Houses}

The changes made to the case study houses are summarised in Table 3. These are grouped under the loose categories of external spaces, structure/building fabric, services, internal spaces, modern devices, and other. These roughly correspond to site, structure/skin, services, space, and stuff building layers (Table 1), respectively. However, some of the changes in external spaces category (e.g. covering of the courtyard with nylon/plastic sheets) relate more to the 'stuff' layer as they are temporary/seasonal. Changes to the structure/building fabric also contain 'stuff' kind of changes (covering of walls with nylon sheets). The 'services' category mainly groups changes related to drainage, water supply and heating (Figure 2), but also includes the creation/refurbishment of service spaces. "Internal spaces" includes mostly change of use of spaces but also refurbishment and the covering up of some spaces. The category "modern devices" includes a variety of additions from communication/entertainment devices such as TVs, computers, to heating, cooling and ventilation equipment, energy-saving light bulbs, and portable electricity generators; some of these could rightly fall within the "services" categories. The final column in Table 3 ("Other") includes any other relevant information about some houses.

Regarding specific changes, all houses have added some kind of modern device, and all, except $\mathrm{CH} 12$, have made changes to internal spaces. Seven of the houses $(\mathrm{CH} 1 / \mathrm{CH} 4 \mathrm{CH} 2, \mathrm{CH} 6, \mathrm{CH} 7, \mathrm{CH} 8$ and $\mathrm{CH} 10$ ) have made changes in every category. Since most of the buildings are owned by the Government (Table 2) some of these changes were instigated/carried out by them. For example, $\mathrm{CH} 1 / \mathrm{CH} 4$ was extensively refurbished by the government in the 1980s (e.g. replacement of electrical wiring, installation of central heating) and again in $\mathbf{2 0 0 0}$ when it was divided into two houses. This division however had other consequences as one of the houses lost its service rooms, necessitating further conversions of the Iwan into a kitchen and the takta-bosh into a bathroom. Another example is $\mathrm{CH} 2$ (Figure 3), which had been converted from a house into a school, and then into a hotel for use by 
foreign workers in the 1980s, and converted back into a house after the current occupants became tenants. 
Table 2: Overview and brief details of houses surveyed and occupants interviewed

\begin{tabular}{|c|c|c|c|c|c|c|c|c|c|c|c|c|c|}
\hline \multirow[t]{2}{*}{ House } & \multirow{2}{*}{$\begin{array}{l}\text { Owner- } \\
\text { ship }\end{array}$} & \multirow{2}{*}{$\begin{array}{l}\text { Length of } \\
\text { Occupancy } \\
\text { (yrs.)\# }\end{array}$} & \multirow{2}{*}{$\begin{array}{l}\text { No. of } \\
\text { Occu- } \\
\text { pants }\end{array}$} & \multicolumn{3}{|c|}{ Occupant Type** } & \multicolumn{2}{|c|}{ Age Range (yrs)** } & \multirow{2}{*}{$\begin{array}{l}\text { No of } \\
\text { Court- } \\
\text { yards }\end{array}$} & \multirow{2}{*}{$\begin{array}{l}\text { No. of } \\
\text { levels }\end{array}$} & \multirow[t]{2}{*}{ No. of rooms } & \multirow[t]{2}{*}{ Service Rooms } & \multirow{2}{*}{$\begin{array}{c}\text { Interviewees ( } 2 \text { per } \\
\text { house) }\end{array}$} \\
\hline & & & & M & $\mathrm{F}$ & C & Adults & Children & & & & & \\
\hline $\mathrm{CH} 1 *$ & Govt. & Over 10 & 9 & 3 & 3 & 3 & $28-65$ & Under 6 & 1 & 6 & $\begin{array}{l}8 \text { with } \text { sardab }^{1} \& \\
\text { neem }\end{array}$ & $\begin{array}{l}\text { Kitchen, toilet } \\
\text { and bath }\end{array}$ & Husband \& Wife \\
\hline $\mathrm{CH} 2$ & Govt. & Over 28 & 7 & 2 & 2 & 4 & $27-769$ & Under 5 & 1 & 4 & $\begin{array}{l}9 \text { with neem } \\
\text { sardab } 2\end{array}$ & $\begin{array}{l}\text { kitchens, toilets, } \\
\text { baths }\end{array}$ & Husband \& Wife \\
\hline $\mathrm{CH} 3$ & Govt. & 30 & 11 & 3 & 3 & 4 & $19-72$ & $5-16$ & 1 & 4 & $\begin{array}{l}8 \text { with the neem } \\
\text { sardab }{ }^{2}\end{array}$ & $\begin{array}{l}\text { kitchens, toilets, } \\
2 \text { baths }\end{array}$ & Housewife \& Son \\
\hline $\mathrm{CH} 4 *$ & Govt. & Over 9 & 5 & 3 & 1 & 1 & $18-53$ & 4 & 1 & 5 & 5 with sardab ${ }^{1}$ & $\begin{array}{l}\text { Kitchen, toilet } \\
\text { and bath }\end{array}$ & $\begin{array}{l}\text { Younger Son \& } \\
\text { Wife of Eder Son }\end{array}$ \\
\hline $\mathrm{CH} 5$ & Govt. & Over 30 & 8 & 1 & 2 & 5 & $31-64$ & $4-15$ & 1 & 4 & $\begin{array}{l}6 \text { with the } \\
\text { sardab }{ }^{1} \& \text { neem } \\
\text { sardab }{ }^{2}\end{array}$ & $\begin{array}{l}\text { Kitchen, toilet } \\
\text { and bath }\end{array}$ & Son \& His Wife \\
\hline $\mathrm{CH} 6$ & Govt. & Less than 1 & 7 & 1 & 2 & 4 & $18-43$ & $5-16$ & 1 & 4 & $\begin{array}{l}5 \text { with the } \\
\text { sardab }^{1}\end{array}$ & $\begin{array}{l}\text { Kitchen, toilet } \\
\text { and bath }\end{array}$ & $\begin{array}{l}\text { Housewife \& } \\
\text { Daughter }\end{array}$ \\
\hline $\mathrm{CH} 7$ & Govt. & 40 & 15 & 7 & 4 & 4 & $18-68$ & $7-16$ & 1 & 4 & $\begin{array}{l}21 \text { with neem } \\
\text { sardab }^{2}\end{array}$ & $\begin{array}{l}\text { 2Kitchen, 2toilet } \\
\text { and } 2 \text { bath }\end{array}$ & $\begin{array}{l}\text { Housewife \& Sister- } \\
\text { in-Law }\end{array}$ \\
\hline $\mathrm{CH} 8$ & Private & Over 60 & 3 & 1 & 2 & - & $29-63$ & - & 1 & 4 & $\begin{array}{l}4 \text { with the } \\
\text { sardab }{ }^{1}\end{array}$ & $\begin{array}{l}\text { Kitchen, toilet } \\
\text { and bath }\end{array}$ & $\begin{array}{l}\text { Husband \& } \\
\text { Daughter }\end{array}$ \\
\hline $\mathrm{CH} 9$ & Private & 38 & 5 & 2 & 1 & 2 & $35-73$ & Under7 & 2 & 4 & $\begin{array}{l}8 \text { with neem } \\
\text { sardab }^{2}\end{array}$ & $\begin{array}{l}2 \text { Kitchen, } 2 \text { toilet } \\
\text { and } 2 \text { bath }\end{array}$ & $\begin{array}{l}\text { Housewife \& } \\
\text { Daughter-in-Law }\end{array}$ \\
\hline $\mathrm{CH} 10$ & Govt. & Over 40 & 26 & 9 & 6 & 11 & 18-79, & Under 1- 17 & 2 & 6 & $\begin{array}{l}21 \text { with neem } \\
\text { sardab }^{2}\end{array}$ & $\begin{array}{l}\text { 2Kitchen, } 2 \text { toilet } \\
\text { and } 2 \text { bath }\end{array}$ & $\begin{array}{l}\text { Grandfather \& His } \\
\text { Son }\end{array}$ \\
\hline $\mathrm{CH} 11$ & Govt. & 42 & 17 & 3 & 4 & 10 & $23-67$ & Newborn-15 & 1 & 4 & $\begin{array}{l}6 \text { with the neem } \\
\text { sardab }{ }^{2}\end{array}$ & $\begin{array}{l}\text { Kitchen, toilet } \\
\text { without bath }\end{array}$ & $\begin{array}{l}\text { Housewife \& } \\
\text { Mother-in-Law }\end{array}$ \\
\hline $\mathrm{CH} 12$ & Private & $\begin{array}{l}\text { Less than } \\
12\end{array}$ & 5 & & 2 & 3 & $\begin{array}{l}\text { Over } \\
40\end{array}$ & $3-7$ & 1 & 4 & $\begin{array}{l}4 \text { with neem } \\
\text { sardab } 2\end{array}$ & $\begin{array}{l}\text { Kitchen, toilet } \\
\text { without bath }\end{array}$ & $\begin{array}{l}\text { Housewife \& her } \\
\text { Sister }\end{array}$ \\
\hline
\end{tabular}

\# At the time of the survey in 2012

*Note: $\mathrm{CH} 1$ and $\mathrm{CH} 4$ are part of a TCH that had been divided into two houses (two households)

${ }^{* *} \mathrm{M}=$ Adult male; $\mathrm{F}=$ Adult Female; $\mathrm{C}=$ Children

${ }^{1}$ Sardab $=$ Basement $;{ }^{2}$ Neem sardab $=$ Mezzanine level between the basement and ground floor 
Table 3: Summary of Changes Made to Case Study Houses

\begin{tabular}{|c|c|c|c|c|c|c|}
\hline \multirow[t]{2}{*}{ HOUSE } & \multicolumn{6}{|c|}{ CHANGES/ADAPTATIONS MADE } \\
\hline & External Spaces & Structure/Building Fabric & Services & Internal Spaces & Modern Devices & Other \\
\hline $\mathrm{CH} 1$ & $\begin{array}{l}\text { The courtyard is covered } \\
\text { with nylon sheets in } \\
\text { winter }\end{array}$ & $\begin{array}{l}\text { Increased the thickness of the } \\
\text { walls to the whole house }\end{array}$ & $\begin{array}{l}\text { Drainage and water } \\
\text { systems in service rooms. } \\
\text { Central cooling and } \\
\text { heating system for whole } \\
\text { house }\end{array}$ & $\begin{array}{l}\text { Converted: Neem sardab (partially } \\
\text { covered up) to living room; Dewakana } \\
\text { in first floor to bedroom; }\end{array}$ & $\begin{array}{l}\text { Adding different types } \\
\text { of modern devices to } \\
\text { the whole house }\end{array}$ & $\begin{array}{l}\mathrm{CH} 1 \text { and } \\
\mathrm{CH} 4 \text { were } \\
\text { previously } 1 \\
\text { house }\end{array}$ \\
\hline $\mathrm{CH} 2$ & $\begin{array}{l}\text { Floors and walls in the } \\
\text { courtyard were covered }\end{array}$ & $\begin{array}{l}\text { Conserved the structure The } \\
\text { external walls for house and } \\
\text { courtyard; Floors and walls } \\
\text { were covered in the living } \\
\text { room }\end{array}$ & $\begin{array}{l}\text { New drainage and water } \\
\text { pipes in service rooms }\end{array}$ & $\begin{array}{l}\text { Converted: Neem sardab to the } \\
\text { kitchen; Kichen to bathroom; Ursi to } \\
\text { the living room; and Dewakana in first } \\
\text { floor to bedroom; the whole sardab } \\
\text { was covered up }\end{array}$ & $\begin{array}{l}\text { Adding different types } \\
\text { of modern device The } \\
\text { whole house }\end{array}$ & \\
\hline $\mathrm{CH} 3$ & $\begin{array}{l}\text { Covered the open space } \\
\text { by adding removable steel } \\
\text { bars and nylon sheets or } \\
\text { tents to the courtyard }\end{array}$ & & $\begin{array}{l}\text { New drainage and water } \\
\text { pipes in service rooms }\end{array}$ & $\begin{array}{l}\text { Neem sardab to reception room; Ursi } \\
\text { to bedroom; Room in the first floor to } \\
\text { kitchen; Iwan (a transition space) into } \\
\text { a bedroom }\end{array}$ & $\begin{array}{l}\text { Adding different types } \\
\text { of modern devices to } \\
\text { the whole house }\end{array}$ & $\begin{array}{l}\text { Half of the } \\
\text { first floor } \\
\text { not used }\end{array}$ \\
\hline $\mathrm{CH} 4$ & $\begin{array}{l}\text { The courtyards is covered } \\
\text { with nylon sheets in } \\
\text { winter and with tents in } \\
\text { the summer }\end{array}$ & All floors and walls covered & $\begin{array}{l}\text { Drainage and water } \\
\text { systems in service rooms. } \\
\text { Central cooling and } \\
\text { heating system for whole } \\
\text { house }\end{array}$ & $\begin{array}{l}\text { Converted: Takta bosh to bathroom; } \\
\text { and Iwan in the first converted to a } \\
\text { kitchen }\end{array}$ & $\begin{array}{l}\text { Adding different types } \\
\text { of modern devices to } \\
\text { the whole house }\end{array}$ & $\begin{array}{l}\mathrm{CH} 1 \text { and } \\
\mathrm{CH} 4 \text { were } \\
\text { previously } 1 \\
\text { house }\end{array}$ \\
\hline $\mathrm{CH} 5$ & & $\begin{array}{l}\text { Some floors and walls were } \\
\text { covered on the ground floor }\end{array}$ & $\begin{array}{l}\text { New drainage and water } \\
\text { pipes in service rooms }\end{array}$ & Converted the Iwan to living room & $\begin{array}{l}\text { Adding different type } \\
\text { of modern devices }\end{array}$ & \\
\hline $\mathrm{CH} 6$ & $\begin{array}{l}\text { Covered the open space } \\
\text { with fixed wood Courtyard }\end{array}$ & $\begin{array}{l}\text { All floors and walls were } \\
\text { covered }\end{array}$ & $\begin{array}{l}\text { Refurbishment of service } \\
\text { rooms in the whole house }\end{array}$ & $\begin{array}{l}\text { Converted: Neem sardab to living } \\
\text { room and kitchen }\end{array}$ & $\begin{array}{l}\text { Adding different type } \\
\text { of modern device to } \\
\text { the whole house }\end{array}$ & \\
\hline $\mathrm{CH} 7$ & $\begin{array}{l}\text { Covered the courtyard } \\
\text { with plastic sheeting }\end{array}$ & $\begin{array}{l}\text { Increased the thickness of } \\
\text { external walls } \\
\text { All floors and some walls were } \\
\text { covered. The whole house }\end{array}$ & $\begin{array}{l}\text { Service rooms created in } \\
\text { the whole house }\end{array}$ & $\begin{array}{l}\text { Neem sardab to bed room, living room } \\
\text { and kitchen; Kitchen to bathroom and } \\
\text { wc; Iwan to bed room; Part of sardab } \\
\text { and whole neem sardab was covered } \\
\text { up }\end{array}$ & $\begin{array}{l}\text { Adding different types } \\
\text { of modern device. The } \\
\text { whole house }\end{array}$ & $\begin{array}{l}\text { House } \\
\text { partitioned } \\
\text { into four } \\
\text { zones }\end{array}$ \\
\hline
\end{tabular}




\begin{tabular}{|c|c|c|c|c|c|c|}
\hline $\mathrm{CH} 8$ & $\begin{array}{l}\text { Covered the open space } \\
\text { with fixed plastic sheeting } \\
\text { and iron bars (courtyard) }\end{array}$ & $\begin{array}{l}\text { Refurbishing structure } \\
\text { All floors and walls were } \\
\text { covered }\end{array}$ & $\begin{array}{l}\text { Refurbishing service } \\
\text { rooms }\end{array}$ & One sardab covered up & $\begin{array}{l}\text { Adding different type } \\
\text { of modern device. The } \\
\text { whole house }\end{array}$ & \\
\hline $\mathrm{CH} 9$ & $\begin{array}{l}\text { Covered the open space } \\
\text { (Courtyard) }\end{array}$ & & $\begin{array}{l}\text { Service rooms created in } \\
\text { the small part of the house } \\
\text { linked to the small } \\
\text { courtyard }\end{array}$ & $\begin{array}{l}\text { Refurbishment of Sardab. Converted: } \\
\text { Ursi to bed room Kitchen to bed room; } \\
\text { Iwan to Kitchen) }\end{array}$ & $\begin{array}{l}\text { Adding different types } \\
\text { of modern device. The } \\
\text { whole house related to } \\
\text { small courtyard }\end{array}$ & $\begin{array}{l}\text { Parts of the } \\
\text { house near } \\
\text { big court- } \\
\text { yard not } \\
\text { used }\end{array}$ \\
\hline $\mathrm{CH} 10$ & $\begin{array}{l}\text { Covered the open space } \\
\text { by adding fixed bars and } \\
\text { plastic sheeting in both } \\
\text { the big and small } \\
\text { courtyards }\end{array}$ & $\begin{array}{l}\text { Rehabilitate structure of the } \\
\text { whole house. Increased the } \\
\text { thickness of all external and } \\
\text { internal walls. All floors and } \\
\text { walls were covered } \\
\end{array}$ & $\begin{array}{l}\text { Rehabilitate services } \\
\text { systems in the whole } \\
\text { house }\end{array}$ & $\begin{array}{l}\text { Converted a room on the first floor, } \\
\text { into a kitchen }\end{array}$ & $\begin{array}{l}\text { Adding different types } \\
\text { of modern device. }\end{array}$ & \\
\hline $\mathrm{CH} 11$ & $\begin{array}{l}\text { Covered the open space } \\
\text { with nylon sheets } \\
\text { (courtyard) }\end{array}$ & & Refurbishing service room & $\begin{array}{l}\text { Converted: Neem sardab to living } \\
\text { room; Ursi to bed room }\end{array}$ & $\begin{array}{l}\text { Adding different types } \\
\text { of modern device to } \\
\text { whole house }\end{array}$ & \\
\hline $\mathrm{CH} 12$ & & & & & $\begin{array}{l}\text { Adding different type } \\
\text { of modern device on } \\
\text { the first floor }\end{array}$ & $\begin{array}{l}\text { Ground floor } \\
\text { not used, } \\
\text { except the } \\
\text { services } \\
\text { room }\end{array}$ \\
\hline
\end{tabular}




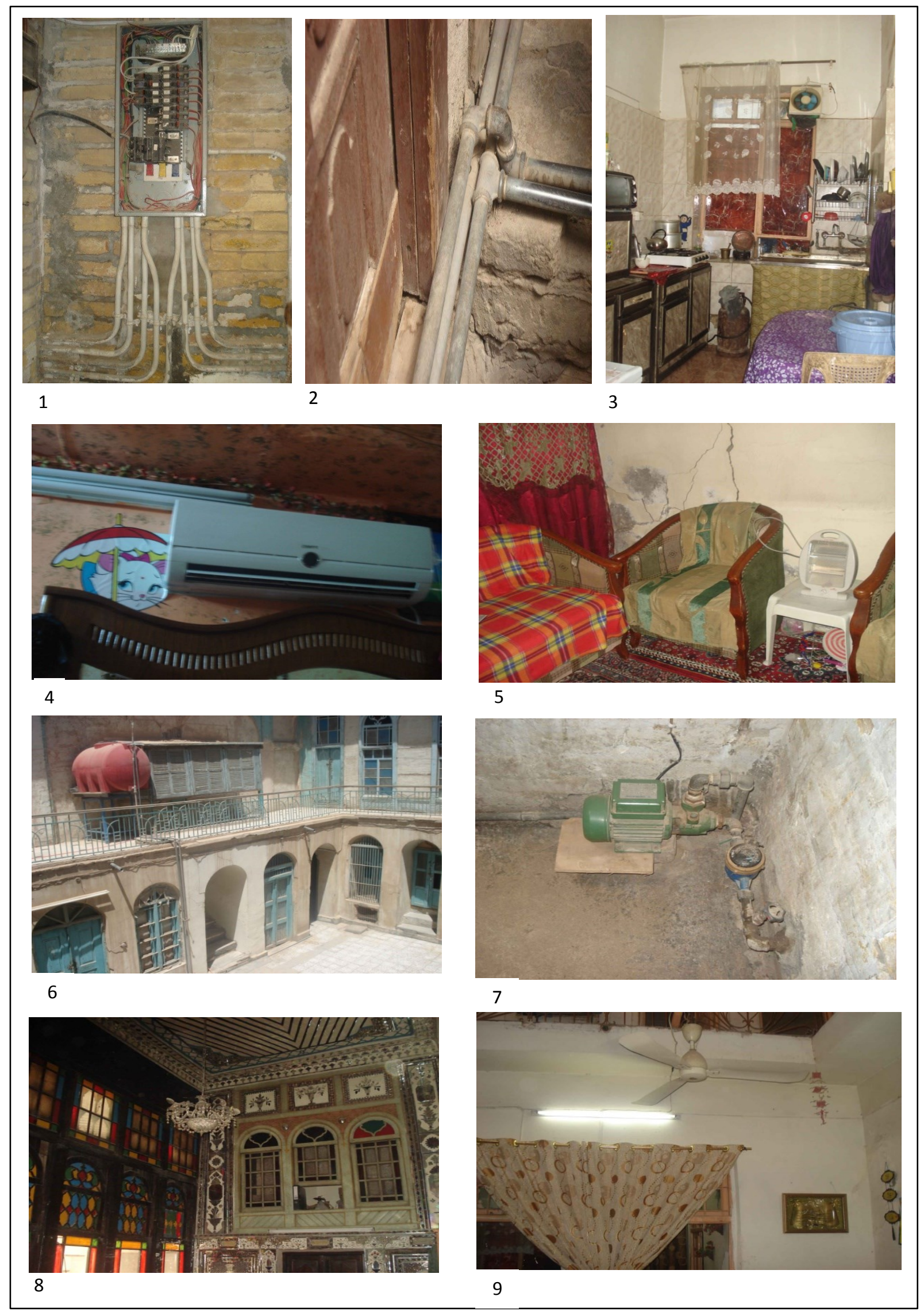


Figure 2: Modification linked to services and modern appliances.

(A) Electrical wiring and water pipes $[1,2=\mathrm{CH} 1$ and $\mathrm{CH} 4]$; (B) Ventilation during space usage $[3=\mathrm{CH} 6]$; (C) Improving cooling, heating in different weather $[4=\mathrm{CH} 7 ; 5=\mathrm{CH} 9]$; (D) Storage/pumping of water in summer $[6=\mathrm{CH} 2 ; 7=\mathrm{CH} 4]$; $(\mathrm{E})$ Enhancing lighting in dust weather $[8=\mathrm{CH} 10 ; 9=\mathrm{CH} 6]$ 

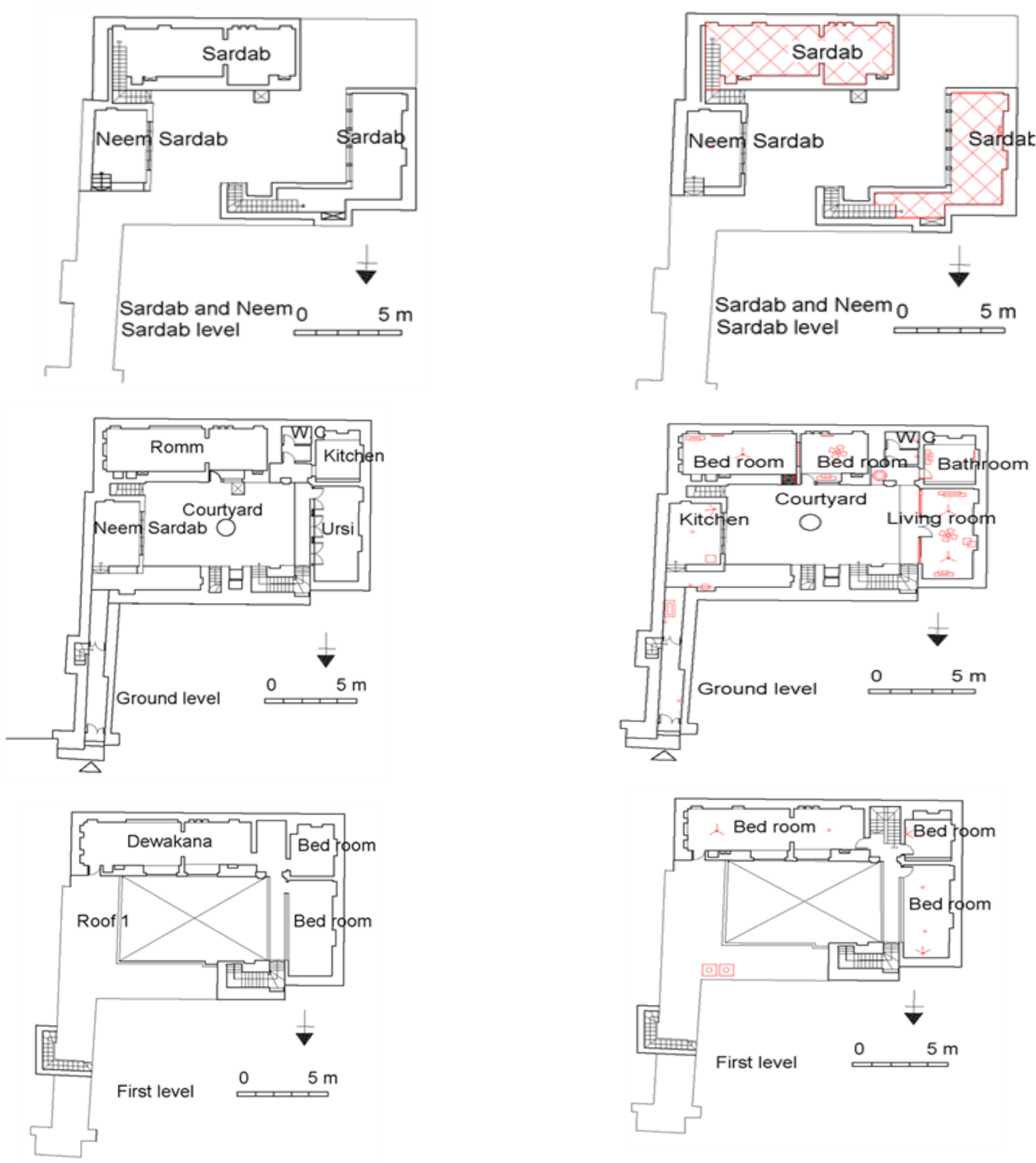

Key:

$\overline{\text { Sardab }}=$ basement

Neem-sardab $=$ the mezzanine level between the basement and ground level.

Takta bosh $=$ space looking to the basement.

Kafish-Kan $=$ the mezzanine level between the ground and first floor. Ursi $=$ family room Iwan $=$ semi-closed space Tarma $=$ semi open space

\begin{tabular}{|c|c|c|}
\hline \multicolumn{3}{|c|}{ Sample } \\
\hline Lighting system & - yूर & 。 \\
\hline Ventilation system & 传 & $!<$ \\
\hline cooling and heating system & $\rightleftarrows$ & 口 \\
\hline Water system & 0 & $\theta$ \\
\hline communication system & $\square$ & \\
\hline electric system & $\square$ & \\
\hline \multicolumn{3}{|c|}{ Pattern } \\
\hline \multicolumn{3}{|l|}{ Abounded } \\
\hline Adding & & \\
\hline
\end{tabular}

Figure 3: Details of $\mathrm{CH} 2$ before (drawings to the left) and after changes (drawings to the right) 


\section{Lifestyle and Adaptations}

The identified themes from the interviews relate to the activities and actions of occupants to respond to environmental (weather) conditions. The human level response achieves partial control of the built environment through the lifestyle of the current users. Lifestyle can be defined as a way of life in relation to everyday activities (Shahril et al. 2012). In this study, it is with specific reference to the activities and relationships of occupants with spaces in and around their homes, at different times of the day or year, and adjustments they make to deal with environmental conditions.

\section{Activities Movement}

This means the flexible movement of different activities in different places, spaces, and levels. The occupants used different places on different levels for the same activity; also, they did different activities in the same place in response to the changing climate factors and weather conditions. These included:

- Gathering - the residents gathered in the courtyard ( $\mathrm{CH} 1-\mathrm{CH} 12)$, the iwan $(\mathrm{CH} 2, \mathrm{CH} 6, \mathrm{CH} 7, \mathrm{CH} 9, \mathrm{CH} 10)$, the neem sardab and the sardab $(\mathrm{CH} 1, \mathrm{CH} 4, \mathrm{CH} 10, \mathrm{CH} 11)$, as well as the living room and ursi $(\mathrm{CH} 1-\mathrm{CH} 12)$, all of which are located on different levels.

- Practising hobbies - the occupants practised hobbies in the sardab and neem-sardab $(\mathrm{CH} 1, \mathrm{CH} 2, \mathrm{CH} 4$, $\mathrm{CH} 8, \mathrm{CH} 10$, and $\mathrm{CH} 11$ ), the courtyard, living rooms, the rooms on the first floor, and the ursi on the ground floor ( $\mathrm{CH} 1-\mathrm{CH} 12)$.

- Sleeping - the families used the living room (All houses except $\mathrm{CH} 8$ ), the sardab and neem sardab (CH1, $\mathrm{CH} 4-\mathrm{CH} 7, \mathrm{CH} 11)$, the bedrooms located on the first or the second floor $(\mathrm{CH} 4, \mathrm{CH} 6-\mathrm{CH} 8, \mathrm{CH} 11)$, the kafish kan $(\mathrm{CH} 10, \mathrm{CH} 11)$ or the roof $(\mathrm{CH} 2, \mathrm{CH} 6)$ and/or the courtyard $(\mathrm{CH} 3)$ if sleeping outside.

- Eating - the residents had meals in the neem sardab $(\mathrm{CH} 1, \mathrm{CH} 4)$, and the ursi located on the first or ground floor ( $\mathrm{CH} 1-\mathrm{CH} 12)$.

- Cooking and washing - usually, the housewives used the kitchen or the courtyard (CH1-CH12); also, they cooked in a room on the first floor ( $\mathrm{CH} 1)$.

2. Modifications of the spaces and users

This refers to approaches which allowed better user control and customization of the environment (Sinclair et.al 2012, p.35). In other words, what the occupants themselves did to the spaces, places, levels in the TCHs. These modifications include:

Alterations to the spaces and building fabric as described above and summarised in Table 3 Some of the changes, especially the temporary changes relating to the "stuff" layer are made mainly to improve the environmental performance of the building. For example, in cold weather, the occupants covered the courtyard with nylon sheeting (all houses except $\mathrm{CH} 5$ and $\mathrm{CH} 12$ - Table 3), added wood or fibre plates ( $\mathrm{CH} 7$, $\mathrm{CH} 8)$, and covered the doors/windows of all the rooms around the interior courtyard with nylon $(\mathrm{CH} 1, \mathrm{CH} 7$, $\mathrm{CH} 8$ ) or blankets ( $\mathrm{CH} 6)$ in winter; all houses also used oriental carpets. In hot weather, some occupants would put up a tent to cover the courtyard (e.g. $\mathrm{CH} 3$ ). In all houses windows will be closed during the day, and kept opened throughout the night. In some cases potted desert plants are put in window openings ( $\mathrm{CH} 11)$. The roof and yard bricks are also washed with water before sleeping at night in all houses, to both cool and remove dust from these surfaces. Also, water was used in the summer in the lower slot of the bad-geer, extended to the sardab ( $\mathrm{CH} 10, \mathrm{CH} 11)$. The walls of TCHs are continuously painted (All houses except $\mathrm{CH} 12$ ). The slot of the bad-geer is closed and covered with a grid during dust storms (All houses except $\mathrm{CH} 3$ and $\mathrm{CH} 12$. Spaces such as the sardab are continuously sterilized with chemicals and incense is burned to improve the smells ( $\mathrm{CH} 1, \mathrm{CH} 8, \mathrm{CH} 9)$. One occupant who had lived in one of the case study houses ( $\mathrm{CH} 9)$ for 38 years observed that:

"We deal with moisture by repeatedly painting the walls or covering them with wood. Also, we continuously sterilize and burn incense in the house to make the house smell nice" (Occ., 17, 2012).

The temporary nature of these alterations, to respond to specific changes in environmental conditions, represent a dynamic aspect of the adaptations made in these houses. 
Other actions (in most houses) include: the addition of modern devices and appliances (described above, and with examples shown in Figure 2); the mobility of occupants with respect to the use of different sections/spaces in the house at different times of the year through vertical movements between levels, and horizontal movements across different spaces on the same level; and the wearing of appropriate clothing to suit weather conditions. It should be pointed out that mobility of occupants may be restricted by the number of people and the usable rooms in the house. For example, in $\mathrm{CH} 7$, which has 15 occupants (Table 2), all the spaces and levels are occupied and the house has been divided into four zones for different sections of the extended family living in the house.

\section{ANALYSIS AND DISCUSSION}

This paper sought to explore questions around the nature of Traditional Courtyard Houses (TCHs) and how they support the lifestyles of current users, the nature and extent of the adaptations that have been made, and how these contribute to the wider theory and practice of building adaptability.

The longevity of TCHs (albeit in varying states of repair) and their structure and robustness does appear to provide some level of support for occupants. For example, allowing some degree of flexibility in the way spaces are used, the ability to make alterations to some spaces and so on. The basic structure itself does provide a passive response to environmental conditions, which include protection from dust storms and the extremes of hot and cold temperatures, through the enclosed courtyard and thick walls, respectively. The fact that modern appliances and other services can be, and have been added to all the case study houses can be seen as further indication that TCHs are adaptable. The partitioning of one of the case study houses ( $\mathrm{CH} 7)$ into four zones is a further indication of flexibility. But on the other hand, the fact that these systems and appliances need to be added suggests that passive features are not now adequate to support the lifestyles of occupants. Furthermore, the covering of walls and windows also limit the functions of spaces, Another aspect is that these additions (e.g. the electrical wiring and water pipes in Figure 3) do appear to be 'add-ons' that have altered the aesthetics of TCHs; a suggestion that adaptations are relatively not easy to achieve.

With regards to the adaptations that have been made, it is observed that changes that had been made to all the houses were mostly related to services (heating, water, electricity), conversions and/or modifications to spaces, and the use of temporary measures (e.g. curtains, plastic sheeting) to enhance the spaces. These changes, it would appear, are intended to improve the performance of the spaces and enhance the comfort of participants. With reference to the dimensions of adaptability depicted in Table 1, changes are mostly in the services, space and stuff layers, given that the structure and site of TCHs are quite immovable. The role of Government (the owner of most houses surveyed - Table 2) appears to be supportive of changes to the fabric as previous major adaptations had been carried out by them (as in the case of $\mathrm{CH} 1, \mathrm{CH} 4$ and $\mathrm{CH} 2$ ). Compliance with building regulations (though not specifically considered in this study), which can be a key constraint in making adaptations to historic buildings such as TCHs (Brand, 1994; Bullen, 2007; Gosling et al. 2013), did not appear to have been an issue; partly because some of the major works had been carried out by the Government itself, and partly due to the fact that most changes are either relatively minor or temporary. But it might also be that occupants don't have the financial ability to make changes, as suggested by one of the interviewees from $\mathrm{CH} 1$ who commented that:

"We use one room for all activities such as sleeping, living, etc. because we cannot adapt all the rooms and so all the others are abandoned. This affects the relationship between the parents, as the husband and wife have an unmarried daughter and son sleeping in the room with us. Sometimes my son slept in a nearby hotel because he found the house was either too cold or too hot" (Occupant 1+2, CH1)

Another dimension of adaptations is in the occupants themselves as evidenced by their movement across different spaces and levels, use of different clothing, etc. While this feature in the case study houses, is not necessarily unique (indeed it reflects the way TCHs are used - Warren and Fethi (1982), it does give rise to another dimension of building adaptability, that is, the adaptability of people to buildings and not just of buildings to suit people, as observed by Brand (1994).In a bid to understand whether there were any underlying patterns to the changes made to case study houses, a comparison of the level of changes (Table 3 ) with the characteristics of houses (Table 2) was made and summarised in Table 4. The top half of the table lists some selected variables from Table 2 against the 'level of changes' (with respect to the proportion of 
change categories covered in Table 3) made to respective houses. The bottom half of Table 4 ranks (from lowest to highest) these variables (e.g. ownership, number of occupants) against the level of changes. This is not intended to be a statistical analysis of the changes (as the sample size is too small for this) but to explore whether there were any underlying patterns to the changes. It is observed that in terms of ownership, two of the three houses that are privately owned have less than a ' $100 \%$ ' of the categories of changes. One would have expected that private ownership gives more freedom to make changes, but this may not be the only factor that determines whether or not adaptations are made to a house. Furthermore, although the privately owned houses ( $\mathrm{CH} 8, \mathrm{CH} 9$ and $\mathrm{CH} 12$ ) have relatively fewer occupants ( 3,5 and 5 , respectively), the comparison of number of occupants against level of changes (Table 4) does not show any proportional link between the two. The comparison of the other variables (number of rooms, years of occupancy) with the level of changes also does not show any proportional link. It may therefore be that enablers for adaptations might be due to other factors (e.g. financial ability as suggested above), which were nor explored in this research.

Table 4: Comparison of Level of Changes with Characteristics of Case Study Houses

\begin{tabular}{|c|c|c|c|c|c|c|c|c|c|c|}
\hline House & \multicolumn{2}{|c|}{ Changes* } & \multicolumn{2}{|l|}{ Ownership } & Length of occupancy (yrs) & \multicolumn{2}{|c|}{ No of Occupants } & \multicolumn{3}{|c|}{ No of Rooms } \\
\hline $\mathrm{CH} 1$ & \multicolumn{2}{|r|}{$100 \%$} & Govt & \multicolumn{2}{|c|}{$10+$} & \multicolumn{2}{|r|}{9} & \multicolumn{3}{|r|}{8} \\
\hline $\mathrm{CH} 2$ & \multicolumn{2}{|r|}{$100 \%$} & \multicolumn{2}{|l|}{ Govt } & $28+$ & \multicolumn{2}{|r|}{7} & & & 9 \\
\hline Ch3 & \multicolumn{2}{|r|}{$80 \%$} & \multicolumn{2}{|l|}{ Govt } & 30 & \multicolumn{2}{|c|}{11} & & & 8 \\
\hline $\mathrm{CH} 4$ & \multicolumn{2}{|r|}{$100 \%$} & Govt & \multicolumn{2}{|c|}{$9+$} & \multicolumn{2}{|r|}{5} & & & 5 \\
\hline $\mathrm{CH} 5$ & \multicolumn{2}{|r|}{$80 \%$} & Govt & \multicolumn{2}{|c|}{$30+$} & \multicolumn{2}{|r|}{8} & & & 6 \\
\hline $\mathrm{CH} 6$ & \multicolumn{2}{|r|}{$100 \%$} & Govt & \multicolumn{2}{|c|}{$<1$} & \multicolumn{2}{|r|}{7} & & & 5 \\
\hline $\mathrm{CH} 7$ & & $100 \%$ & Govt & & 40 & & 15 & & & 21 \\
\hline $\mathrm{CH} 8$ & & $100 \%$ & Private & & $60+$ & & 3 & & & 4 \\
\hline $\mathrm{CH} 9$ & & $80 \%$ & Private & & 38 & & 5 & & & 8 \\
\hline $\mathrm{CH} 10$ & & $100 \%$ & Govt & & $40+$ & & 26 & & & 21 \\
\hline $\mathrm{CH} 11$ & & $80 \%$ & Govt & & 42 & & 17 & & & 6 \\
\hline $\mathrm{CH} 12$ & & $20 \%$ & Private & & $<12$ & & 5 & & & 4 \\
\hline & & & & & Changes Vs. & & & & & \\
\hline & Iner & hip & No of Occ & upar & No. of & Rooms & Year & rs of O & ccupancy & \\
\hline & $0 \%$ & Private & $100 \%$ & 3 & $100 \%$ & 4 rooms & & $.00 \%$ & 1 & \\
\hline & $0 \%$ & Govt & $100 \%$ & 5 & $20 \%$ & 4 rooms & & $.00 \%$ & 9 & \\
\hline & $0 \%$ & Govt & $80 \%$ & 5 & $100 \%$ & 5 rooms & & $.00 \%$ & 10 & \\
\hline & $0 \%$ & Private & $20 \%$ & 5 & $100 \%$ & 5 rooms & & $20 \%$ & 12 & \\
\hline & $0 \%$ & Govt & $100 \%$ & 7 & $80 \%$ & 6 rooms & & $.00 \%$ & 28 & \\
\hline & $0 \%$ & Govt & $100 \%$ & 7 & $80 \%$ & 6 rooms & & $80 \%$ & 30 & \\
\hline & $0 \%$ & Govt & $80 \%$ & 8 & $100 \%$ & 8 rooms & & $80 \%$ & 30 & \\
\hline & $0 \%$ & Govt & $100 \%$ & 9 & $80 \%$ & 8 rooms & & $80 \%$ & 38 & \\
\hline & $0 \%$ & Govt & $80 \%$ & 11 & $80 \%$ & 8 rooms & & $.00 \%$ & 40 & \\
\hline & $0 \%$ & Govt & $100 \%$ & 15 & $100 \%$ & 9 rooms & & $.00 \%$ & 40 & \\
\hline & $0 \%$ & Private & $80 \%$ & 17 & $100 \%$ & 21 rooms & & $80 \%$ & 42 & \\
\hline & $0 \%$ & Govt & $100 \%$ & 26 & $100 \%$ & 21 rooms & & $.00 \%$ & 60 & \\
\hline
\end{tabular}

*With respect to categories covered in Table 3

However, it is evident that both types of changes identified in this study are linked to building performance and the need to enhance the comfort of occupants. This is in line with other studies (e.g. Gosling et al. 2013) that link the need for adaptations to building performance. Figure 4 shows these interrelationships: TCHs have passive features that support the lifestyles of occupants (in terms of movement and lifestyle modifications), and which contribute to some level of thermal comfort. However, when these passive 
features and occupant adjustments are not adequate to respond to various environmental conditions, there is a need for adaptations of spaces, which is not just confined to changes to the fabric, but also the installation of modern appliances and systems. The enablers for actually making the changes though, might be due to other factors, which can be the subject of further research.

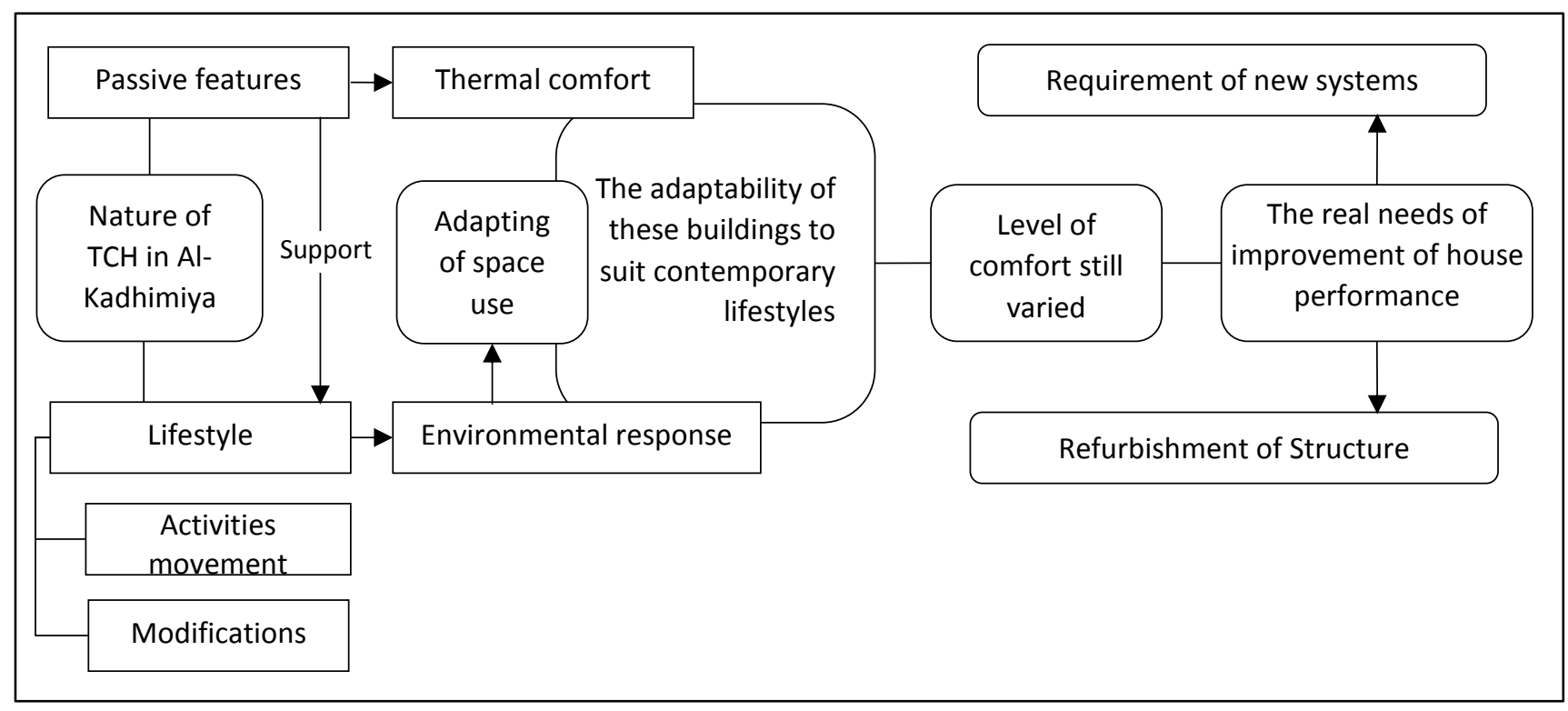

Figure 4: Adaptation Model of TCH in Al-Kadhimiya

\section{CONCLUSIONS}

The aim of this paper was to explore the adaptations that have been made to Traditional Courtyard Houses (TCH) in Baghdad, Iraq, with a view to developing an understanding of how these compare with current stateof-the art on building adaptability. A case study approach was adopted and this involved a survey of $12 \mathrm{TCHs}$ in the Al-Kadhimiya area of Baghdad, and interviews with 24 residents ( 2 per surveyed house). From the analysis of the findings, the following conclusions can be drawn.

Firstly, the nature and pattern of adaptations to the building, which were mainly in the space and services layers, are broadly in line with current understanding of the relationship between adaptability and building layers (Brand, 1994; Schmidt III and Austin, 2016). For example, the fact services were not integrated in the structure of TCHs when they were constructed suggests a separation between these layers, and the relative ease therefore of adding services (Figure 2). However, since the structure is not independent from spaces (walls and partitions are essentially load bearing), changes to spaces is relatively less straightforward, except if this is within a space (as in the changes made to $\mathrm{CH} 1,4$ and 2) or divisions along existing partitions (e.g. separating $\mathrm{CH} 1$ into two houses). The link between the need for adaptation and building performance (Gosling et al. 2013) is also supported in this study (Figure 4). However, no clear patterns with respect to underlying enablers for adapting the case study houses (Table 4) were established.

Secondly, the role of occupants (users) is a key aspect of building adaptability. Although this fact is implicitly acknowledged in the various dimensions of adaptability illustrated in Table 1 (i.e. the adjustable and versatile categories which are user-driven) and other authors (e.g. Brand, 1994; Schmidt III and Austin, 2016), much research on building adaptability has focused on adaptations to the building fabric. This study however shows that user changes can be complex and varied, are influenced by lifestyles and driven by the need to maintain a level of comfort. The ongoing, cyclical interaction of occupants and the building fabric, which is conceptualised in the TCH adaptation model in Figure 4, shows that changes to the building fabric is necessitated when inbuilt passive elements and actions of users and no longer adequate to provide a satisfactory level of comfort for users. This is similar to the Building Adaptation System by Gosling et al. (2013), which suggests that change is fuelled by a failure of the building system to perform satisfactorily. 
It should be noted however, that whilst the above conclusions do provide insights into building adaptability, the findings are only limited to the TCHs considered in this study. More extensive studies of a wider sample of TCHs and of other building types are required to gain more insight into the role of users in building adaptability. Another limitation is that the fuller extent of the enabling and inhibiting factors of the adaptations made were not explored; for example, issues around building regulations and how changes complied with these, economic factors, etc. This was mainly due to the restrictive timescale and security issues around the data collection process. These limitations clearly provide areas for further research, as well as further exploration of the TCH adaptation model (Figure 4) for other building types.

\section{REFERENCES}

Agha, R. (2016). The Role of Intelligent Systems in Traditional Courtyard Houses in Bagdad, Iraq. Unpublished PhD Thesis, Newcastle University, Newcastle upon Tyne, UK.

Agha, R. (2015) "Traditional environmental performance: The impact of active systems upon the courtyard house type, Iraq", Journal of Sustainable Development. 8(8) pp. 28-41

Al-Akkam, A. J. M. (2013) "Urban Heritage in Baghdad: Toward a comprehensive sustainable Framework", International Journal of Sustainable Development 6 (2): 39-55.

Al-Azzawi, S. H. (1996A) "Seasonal impact of climate on the pattern of urban family life: Indigenous courtyard houses of Baghdad regions of the hot dry climates", Renewable Energy 8 (1-4): 283-288.

Al-Azzawi, S. H. (1996B) "Daily impact of climate on the pattern of urban family life: Indigenous courtyard houses of Baghdad regions of the hot-dry climates Part I: Daily shifts or daily movements in summer", Renewable Energy 8 (1-4): 289-294.

Al-Zubaidi, M. S. S. (2007) The sustainability potential of traditional architecture in the Arab world-with reference to domestic buildings in the UAE. UK. University of Huddersfield Repository.

Arge, K. (2005), "Adaptable office buildings: theory and practice," Facilities, 23(3/4), 119-127

Azadi, M. (2008) A study on city centre regeneration: A comparative analysis of two different approaches to the revitalisation of historic city centres in Iran. UK. Newcastle University.

Beadle, K., Gibb, A., Austin, S., Fuster, A. and Madden, P. (2008) Adaptable futures: setting the agenda? In proceedings of the 1st I3CON International Conference, Loughborough University, Loughborough, UK, 14-16 May

Brand, S. (1994), How Buildings Learn: What happens after they're built, Penguin Books, New York

Bullen, P. A. (2007), "Adaptive reuse and sustainability of commercial buildings," Facilities, 25(1/2), 20-31

El-Shorbagy, A. (2010) "Traditional Islamic-Arab house: vocabulary and syntax", International Journal of Civil and Environmental Engendering IJCEE-IJENS 10 (04) 15-20.

Flyvbjerg, B. (2006) "Five Misunderstandings about case study research, Qualitative Inquiry", Sage Publications 12 (2): 219-245.

Goh, Ai Tee. (2010) Courtyard housing in the UK: potentials for high density low energy urban housing. UK. University of Liverpool.

Goh, A. T. and Sibley, M. (2009) "The users' perspectives of performance of courtyard house type in the UK." PLEA2009 $26^{\text {th }}$ Conference on Passive and Low Energy Architecture, Quebec, Canada, 22-24 June.

Gosling, J., Sassi, P., Naim, M., and Lark, R. (2013), "Adaptable buildings: a systems approach," Sustainable Cities and Society, 7, 44-51.

Kelly, G., Schmidt III, R., Dainty, A. and Story, V. (2011), Improving the design of adaptable buildings through effective feedback in use, in Proceedings of the CIB Management and Innovation for a Sustainable Built Environment conference, Amsterdam, The Netherlands, 20-23 June 
Leylian, M.R.; Amirkhani A.; Bemanian, M. R.; and Abedi, M. (2010) "Design principles in the hot and arid climate of Iran, the case of Kashan", Academic Research 2 (5).

Muhaisen, A. S. (2006) "Shading simulation of the courtyard form in different climatic regions", Building and Environment 41 (12): 1731-1741.

Schmidt III, R., Eguchi, T., Austin, S. and Gibb, A. (2010), "What is the meaning of adaptability in the building industry?", in Chica, Elguezabal, Meno \& Amundarain (Eds.), $16^{\text {th }}$ International Conference on Open and Sustainable Buildings, CIB 104, Bilbao, Spain, 17-19 May, pp. 227-236.

Schmidt III, R. and Austin, S. (2016), Adaptable Architecture: Theory and practice Abingdon, Oxon, UK, Routledge.

Shahril, M. A.; Abdullah, S. A.; and Aminatuzuhariah, M. A. (2012) "Lifestyle orientation and the residential environment: an exploratory review", Procedia -Social and Behavioural Sciences, 49: 304-309.

Shokouhian, M.; Soflaee, F.; and Nikkhah, F. (2007) "Environmental effect of the courtyard in the sustainable architecture of Iran (cold regions)", $2^{\text {nd }}$ PALENC Conference and $28^{\text {th }}$ AIVC Conference on Building Low Energy Cooling and Advanced Ventilation Technologies in the $21^{\text {st }}$ Century.

Sinclair, B.R.; Mousazadeh, S.; and Safarzadeh, G. (2012) "Agility, adaptability, and appropriateness: Conceiving, crafting, and constructing an architecture of the $21^{\text {st }}$ century", ARCC Journal. 9:1 pp.35-43.

Thompson, M., Cooper, I. and Gething, B. (2014), The business case for adapting buildings to climate change: niche or mainstream? Innovate UK, Technology Strategy Board (available from: https://www.gov.uk/government/publications/the-business-case-for-adapting-buildings-to-climate-

change, accessed 29 Sept 2015)

Warren, J. and Fethi, I. (1982), Traditional Houses in Baghdad, Coach Publishing House Limited, Horsham, England.

Webster, M. D. (2007), "Structural design for adaptability and deconstruction: a strategy for closing the materials loop and increasing building value," New Horizons and Better Practices, pp. 1-6 (available from: http://ascelibrary.org/doi/abs/10.1061/40946(248)27, accessed 30 October 2014)

Yang, Z. (2007) Ecological design values of traditional urban courtyard dwellings: a two phase study at 1st to 10th lanes, Dongsi neighbourhood, Beijing. UK. University of Newcastle upon Tyne: 344.

Yin, R. K. (2003) Case Study Research: Design and methods. Sage Publications, Thousand Oaks. 